\title{
ESTRUTURAS GEOELÉTRICA E HIDROQUÍMICA DO SISTEMA AQUÍFERO CRISTALINO DA BACIA DO ALTO RIO CURAÇÁ, SEMI-ÁRIDO DA BAHIA
}

\author{
Olivar Antonio Lima de Lima
}

Recebido em 16 junho, 2009 / Aceito em 29 abril, 2010

Received on June 16, 2009 / Accepted on April 29, 2010

\begin{abstract}
In this work we discuss a geophysical-hydrogeological strategy proposed to explore rationally the groundwater stored in the semi-arid terrains, such as those of the upper Curaçá river basin, Bahia. Three main subjects were considered and solved in this study. The first one was to develop a conceptual geohydrologic model to represent the water storage and transmission within the aquifer zones of the area. Based on surface and aero-geophysical information and on geological data obtained in deep cored mining-wells we propose the model to consist of: (i) a thick layer of alluvial deposits and weathered rocks (saprolites) having up to $30 \mathrm{~m}$ thickness, covering almost continuously the Curaçá river plain and those of their tributaries; and (ii) large and wide belts of densely fractured rocks, laterally and vertically alternating with zones of impervious crystalline basement. These belts of open, subvertical fracturing may reach more than $500 \mathrm{~m}$ in width and depths larger than $300 \mathrm{~m}$. The second was to optimize a geoelectrical procedure capable of imaging, with good spatial resolution, these complexes underground reservoirs. Thus, a two-dimensional scheme of IP-resistivity imaging was performed with a closely spaced association of deep vertical electrical soundings. The third was to search and explain the mechanisms and processes responsible for the high water salinization in the wells drilled in this system. Based on a simplified model for a steady-state, two-dimensional flow of water in a water-table homogeneous and isotropic aquifer, we suggest this salt concentration process is mainly due to the intense and almost continuous evapo-transpiration, that characterizes the semi-arid lands. This process acts over a hydraulic circulating system controlled by the terrain topography. The circulation cells have different sizes and depth of propagation, the salt accumulation being concentrated in the smaller cells.
\end{abstract}

Keywords: crystalline aquifers, geoelectrical structure, saltiness.

RESUMO. Neste trabalho se analisa uma estratégia geofísico-hidrogeológica proposta para explorar racionalmente a água subterrânea armazenada nos terrenos cristalinos semi-áridos, como aqueles da bacia do alto rio Curaçá, Bahia. Num estudo integrado, três principais problemas foram considerados e resolvidos. 0 primeiro envolveu a proposição de um modelo hidrogeológico conceitual para representar o armazenamento e a transmissão de água no sistema aquífero da área. Usando informações geofísicas aéreas e terrestres com dados geológicos de testemunhos de sondagens, propõe-se um modelo consistindo de: (i) uma cobertura aluvionar e de saprólitos, com cerca de 20 a 30 m de espessura e que se estende, continuamente, ao longo da planície do rio Curaçá e de seus tributários; e (ii) zonas largas e extensas de densos e profundos fraturamentos subverticais, geralmente abertos e que formam faixas com mais de $500 \mathrm{~m}$ de largura e profundidades maiores que $300 \mathrm{~m}$, separadas entre si por ombreiras de rocha cristalina mais fechada. 0 segundo consistiu em aperfeiçoar um procedimento geoelétrico capaz de imagear, com boa resolução espacial, esses complexos reservatórios subterrâneos de água. Assim, um esquema de imageamento bidimensional de IP-resistividade foi realizado através de um adensamento lateral da amostragem geoelétrica por sondagens verticais e de um aumento na profundidade de investigação, usando uma instrumentação mais potente. 0 terceiro foi pesquisar e explicar os mecanismos e processos responsáveis pela alta salinização da água observada em poços perfurados nesse sistema. Usando um modelo simplificado de fluxo bidimensional estacionário, num aquífero livre, homogêneo e isotrópico, se sugere que a salinização se deve, principalmente, ao quase-contínuo e intenso processo de evapo-transpiração, característico das zonas semi-áridas. Tal processo atua sobre um sistema de circulação hidráulica controlado pela topografia do terreno, o qual se processa em células de diferentes dimensões laterais e profundidades, sendo que é nas mais rasas que se concentram os sais.

Palavras-chave: aquíferos cristalinos, estrutura geoelétrica, salinização.

Centro de Pesquisa em Geofísica e Geologia da Universidade Federal da Bahia, Rua Barão de Jeremoabo s/n, Campus Universitário de Ondina, 41170-290 Salvador, BA, Brasil. Tel.: (71) 3283-8597; Fax: (71) 3283-8501 - E-mail: olivar@cpgg.ufba.br 


\section{INTRODUÇÃo}

0 Estado da Bahia tem mais de 50\% de seu território inserido no Polígono das Secas. Nessa zona semi-árida, os índices pluviométricos estão normalmente abaixo de $600 \mathrm{~mm} / \mathrm{ano}$ e, por causa de uma insolação elevada, a evapo-transpiração da água, via de regra suplanta, em muito, a precipitação. Em termos geológicos, quase $60 \%$ do semi-árido baiano é constituído por terrenos cristalinos pré-cambrianos que fazem parte do chamado Cráton do São Francisco (Barbosa \& Dominguez, 1996). Numa grande parcela desses terrenos, a água superficial é escassa e a única alternativa viável e permanente para suprimento das populações é a exploração de água subterrânea.

A locação de poços em aquíferos cristalinos é efetuada, dominantemente, usando critérios hidrogeológicos com base em imagens aéreas da superfície terrestre e na análise de estruturas rúpteis nas rochas, observadas em afloramentos. A estatística da produção de água em poços perfurados até uma profundidade média de 70 m mostra uma grande proporção de poços secos (35\%). As descargas específicas são normalmente baixas, variando de 0,08 a $1,72 \mathrm{~m}^{3} / \mathrm{h} / \mathrm{m}$, com média de $0,15 \mathrm{~m}^{3} / \mathrm{h} / \mathrm{m}$. Do ponto de vista hidroquímico têm sido propostas correlações entre salinidade da água, profundidades de entradas de água e densidade da cobertura vegetal da bacia. Em geral, a salinidade varia de 120 a $26.900 \mathrm{mg} / \mathrm{l}$ de sais dissolvidos, com uma média de $5.097 \mathrm{mg} / \mathrm{l}$.

Por causa de condicionamentos geológico-estruturais peculiares, as zonas aquíferas em fissuras de rochas cristalinas são limitadas lateralmente, se localizando, normalmente, em faixas estreitas, sinuosas e interconectadas, que acompanham zonas de falhas e fraturamentos regionais. Por isso, formam reservatórios heterogêneos e de geometrias complicadas, o que muito dificulta suas explorações. Tais dificuldades têm gerado sérios preconceitos, dentre os quais se destaca a presunção de que não existe água subterrânea no ambiente das rochas cristalinas do Nordeste ou que, quando ela existe, é muito salina para uso.

No entanto, existem as seguintes evidências factuais que garantem a ocorrência de zonas aquíferas, contendo quantidades expressivas de água de qualidade razoável, suficientes para suprir populações e rebanhos em suas circunvizinhanças: (i) observações diretas em túneis, galerias e poços testemunhados em minas subterrâneas, tais como a da Mineração Caraíba, no município de Jaguararí - BA, revelam a presença de abundantes fraturamentos até profundidades superiores a $300 \mathrm{~m}$; (ii) locações de furos apoiadas em critérios seguros de geologia e geofísica têm resultado em poços de alta produtividade em rochas cristalinas, com profundidades de cerca de $200 \mathrm{~m}$ (Ferreira \& Stevanato,
2003); (iii) as variações de qualidade das águas subterrâneas não são aleatórias, mas seguem tendências espaciais, locais e regionais, sendo frequente a observação de variações ao longo do fluxo subterrâneo, assim como de mudanças na qualidade da água com o aumento do tempo de bombeio dos poços.

Há quase duas décadas se desenvolvem no Centro de Pesquisa em Geofísica e Geologia da Universidade Federal da Bahia (CPGG/UFBA) pesquisas aplicadas com 0 intuito de elaborar modelos hidrogeológicos apropriados para sistemas aquíferos cristalinos, assim como de integrar metodologias e procedimentos geofísicos para delinear compartimentos aquíferos exploráveis nas rochas cristalinas do semi-árido baiano (Medeiros \& Lima, 1990, 1999; Ferreira, 1999; Pinheiro Neto, 2000). Neste trabalho são apresentados os resultados de estudos geológicos e geofísicos conduzidos para entender e explicar a geometria tridimensional, as propriedades de armazenamento e transmissão, e a qualidade das águas armazenadas no sistema aquífero cristalino da região de Pilar, bacia do alto rio Curaçá, Bahia (Fig. 1). Tais resultados são essenciais para 0 efetivo planejamento do uso conservativo da água subterrânea, para atender tanto 0 suprimento humano quanto a atividade agrícola e pastoril planejada para a área.

Para alcançar esses objetivos foram utilizados, de forma integrada, dados geológicos e geofísicos de levantamentos aéreos e terrestres já executados com fins de exploração mineral, com novos dados geológicos, geofísicos e geoquímicos levantados durante a realização do projeto. As principais motivações para a execução desses trabalhos foram: (i) a importância econômica da área como pólo de mineração no estado, e que poderá se tornar também um importante centro agropastoril, caso haja maior disponibilidade de água; (ii) a representatividade da área como típica do geosistema hídrico cristalino que cobre grande parcela do semi-árido baiano e nordestino.

\section{CONDIÇÕES GEOLÓGICAS E HIDROLÓGICAS REGIONAIS}

Na região da bacia hidrográfica do rio Curaçá, que engloba áreas dos municípios de Jaguarari, Curaçá, Juazeiro e Uauá, há dois terrenos geologicamente distintos, separados por uma extensa zona de falha transcorrente, chamada Falha Morro do Serrote (Fig. 1): (i) a oeste da falha, ocorre um domínio constituído de migmatitos e gnaisses foliados/bandeados ao longo da orientação N5E e mergulhos subverticais, tanto para leste quanto para oeste. Possuem composições tonalíticas a granodioríticas, e contêm corpos intrusivos máfico-ultramáficos, metamorfisados em fácies granulíticos. As rochas intrusivas incluem as mineralizações sulfetadas de cobre que estão em exploração na área; (ii) 0 


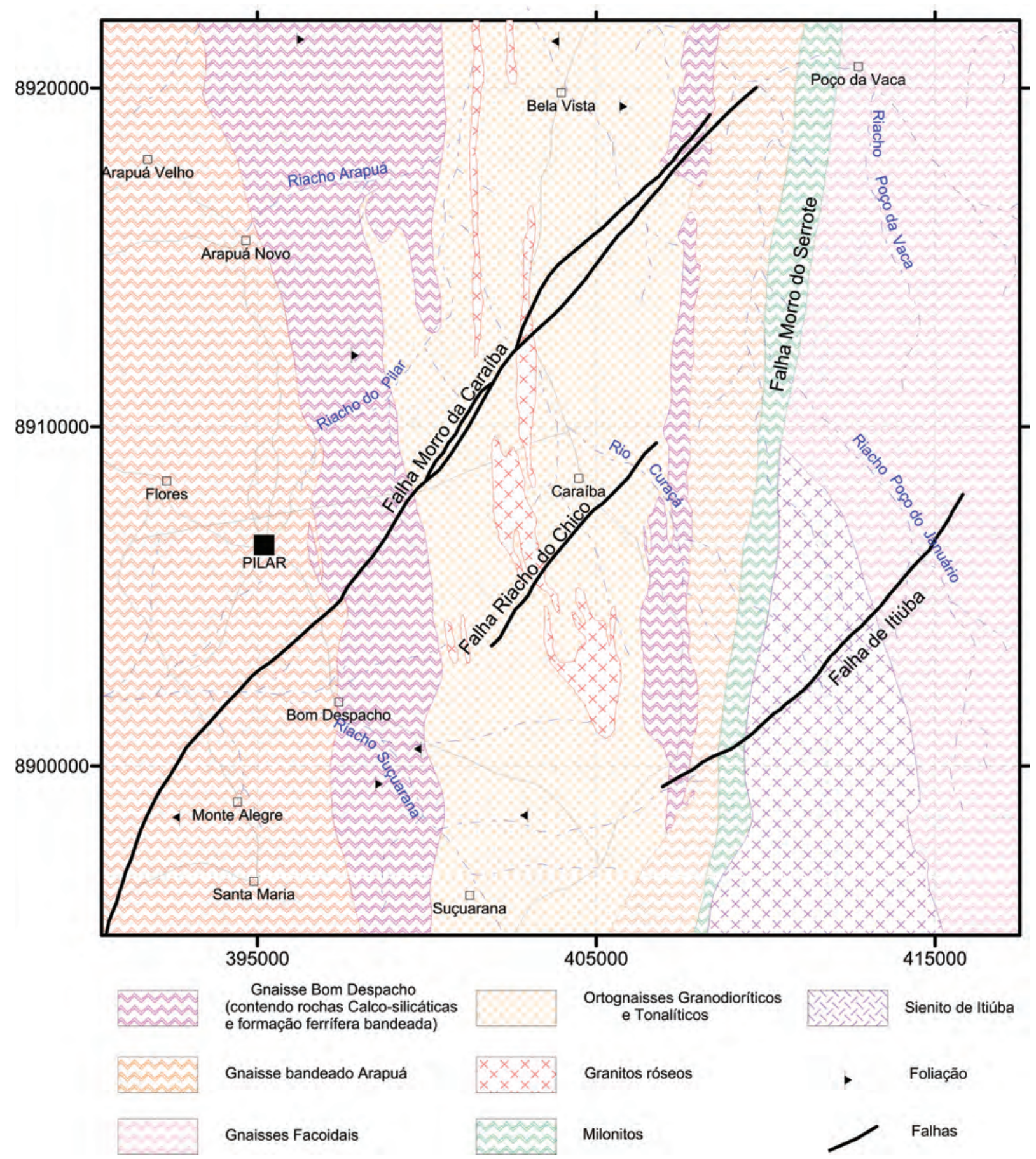

Figura 1 - Mapa geológico da região do alto vale do rio Curaçá, Bahia, composto em 1997 no CPGG/UFBA por Sá, E.P.

terreno de leste é constituído por granitóides mais homogêneos, de fácies anfibolítico, isto é, mais baixo que os do terreno do oeste. Suas estruturas planares estão orientadas, principalmente, em azimutes $\mathrm{N} 120^{\circ}-\mathrm{N} 150^{\circ}$, que tendem a Norte-Sul ao se apro- ximarem da Falha Morro do Serrote, ruptura geológica que favoreceu 0 alojamento de corpos intrusivos de composição sienítica (Delgado \& Souza, 1975; Jardim de Sá \& Reinhardt, 1984; Oliveira, 1998). 
A zona de Falha Morro do Serrote possui traço curvo e segmentado e uma forte componente de deslocamento horizontal. Esta zona de falha subdivide a área em duas zonas estruturais distintas: (i) a de oeste caracterizada por deformações rúpteis de orientações preferenciais N-S e mergulhos subverticais (coincidentes com a orientação da foliação e/ou bandeamento gnáissico), associadas com sistemas de fraturamentos conjugados NE-SW e NW-SE, também de mergulhos elevados. As primeiras parecem ter sido originadas por esforços primários extensionais e coincidem com a orientação de corpos gabro-anortosíticos alojados concordantemente nos gnaisses e migmatitos. Os pares de fraturamentos conjugados indicam esforços primários cisalhantes; (ii) a de leste, é representada por deformações dúcteis na forma de arcos sigmoidais, associadas a ruturas de orientações preferenciais NW-SE e NE-SW.

Em termos de estruturas frágeis, as fraturas e falhas na parte ocidental da área mostram ampla dispersão direcional, com predomínio de orientações entre $N 50^{\circ}-80^{\circ} \mathrm{E}$ e mergulhos acentuados para NE, e $\mathrm{N} 40^{\circ}-50^{\circ} \mathrm{W}$ e mergulhos elevados para NW (Lima, 2007). Estas orientações estão consistentes com aquelas dos lineamentos observados no mapa aeromagnético da área (Fig. 2). Há também abundantes fraturas de orientação paralela à da foliação gnáissica. Existem fortes indicações em afloramentos de que no final da história deformacional da região, eventos extensionais tiveram papel importante na abertura, mesmo de rupturas que anteriormente se encontravam fechadas. Os principais elementos estruturais observados, associados ao armazenamento e à transmissão de fluidos, são: (i) conjuntos de fraturas e de zonas de cisalhamento paralelas à foliação primária, com mergulhos tanto para leste quanto para oeste, criando eixos de convergências de fluxos; (ii) estruturas rúpteis, representadas por fraturas de cisalhamento e falhas, em conjuntos conjugados nas direções $N 50^{\circ}-80^{\circ} \mathrm{E}$ e $\mathrm{N} 40^{\circ}-50^{\circ} \mathrm{W}$.

A Figura 3 contém o perfil geológico do poço VCD-4 testemunhado pelo programa de exploração da Mineração Caraíba, descrito basicamente em termos da densidade de fraturas observada nos testemunhos, em função da profundidade. 0 furo é inclinado de $45^{\circ}$ com a horizontal, cujo azimute é N270 ${ }^{\circ}$. Os $325 \mathrm{~m}$ continuamente amostrados compõem uma profundidade equivalente a $220 \mathrm{~m}$. Abaixo de uma camada de solo, com saprólito e rocha semi-alterada muito fraturada até cerca de $10 \mathrm{~m}$ de espessura vertical, há uma zona de rocha sã, compacta, na qual se intercalam zonas intensamente fraturadas de larguras variadas, sem padrões de distribuição definidos. Há uma zona densa de fraturas, de grande extensão lateral, que se estende entre 90 e $180 \mathrm{~m}$, ao longo do furo. Várias zonas mais delgadas de rocha crista- lina densamente fraturada ocorrem até profundidades equivalentes a $200 \mathrm{~m}$. Admitindo que as fraturas de diferentes orientações sejam dominantemente verticais, compôs-se a estrutura aquífera lateral esquematizada na Figura 3. Nesta figura esquemática, os mergulhos das fraturas são supostos essencialmente verticais, em conformidade com a geologia da área.

No perfil da Figura 4, construído com os dados do furo VCD6 , tem-se um intervalo superior de rocha pouco alterada, mas com alta densidade de fraturas até uma profundidade equivalente a $15 \mathrm{~m}$. Em seguida, ocorrem rochas cristalinas com zonas localizadas de fraturamentos densos até o final do furo. Também não há regularidade nos padrões dos fraturamentos, mas é possível reconhecer, pelo menos, três importantes intervalos que podem constituir zonas aquíferas. Admitindo, novamente, que os sistemas de fraturas seccionados pelo furo sejam dominantemente verticais, é razoável propor a estrutura aquífera esquematizada na Figura 4, para a porção rochosa abaixo da seção do furo.

Os seis outros furos liberados pela Mineração Caraíba mostram, essencialmente, resultados equivalentes em termos de zonas de altas densidades de fraturas lateralmente distribuídas nas rochas cristalinas gnáissico-migmatíiticas da região. Em todos os casos, destaca-se a ocorrência de zonas fraturadas seccionadas em profundidades equivalentes a $200 \mathrm{~m}$. As localizações desses furos estão indicadas no mapa da Figura 5.

0 mapa da Figura 5 mostra a topografia e a rede de drenagem da área estudada com geofísica terrestre na bacia do Curaçá. Este modelado do relevo foi obtido por altimetria GPS durante a execução do levantamento aerogeofísico do projeto Riacho Seco/Andorinha, realizado para a Companhia Baiana de Pesquisa Mineral (CBPM) que, gentilmente, cedeu ao CPGG/UFBA a parte relativa ao alto curso do rio Curaçá para uso nesta pesquisa.

Uma rede de drenagem constitui o conjunto dos canais naturais de escoamento das águas pluviais, que se desenvolvem em zonas de fraqueza das unidades geológicas mais superficiais de uma bacia. 0 padrão de drenagem das águas pluviais na superfície terrestre mantém estreita relação com a natureza, composição e estruturas internas de seu substrato geológico (Domenico \& Schwartz, 1997). Em combinação com 0 clima e a vegetação, exerce importante papel na modelagem do relevo superficial e na evolução pedogenética de uma bacia.

Na área estudada, os sulcos das correntes efêmeras são normalmente estreitos (poucos metros a dezenas de metros de larguras), e se encaixam em planícies de inundação cujas larguras podem variar de poucas dezenas de metros nas regiões de cabeceiras, até algumas centenas a milhares de metros nas regiões mais aplainadas dos cursos inferiores. Essas planícies estão in- 


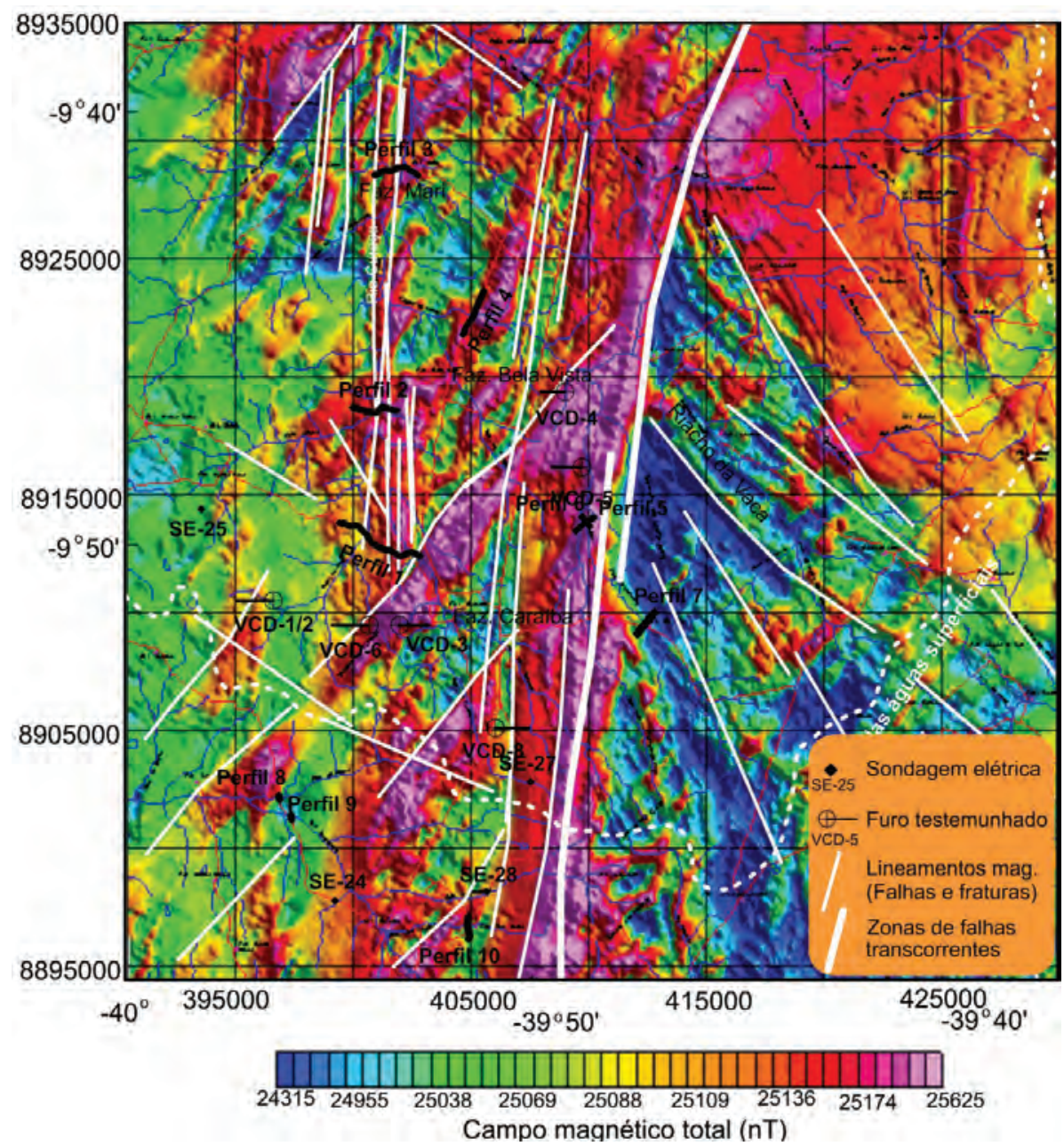

Figura 2 - Mapa de contorno do campo geomagnético total e principais lineamentos estruturais na região da bacia do alto rio Curaçá, Bahia.

variavelmente preenchidas por depósitos aluviais recentes, de constituição dominantemente arenosa embora, localmente, ocorram intervalos de composição mais argilosa (localmente chamados de "fofos").

Observa-se na Figura 5 que 0 sistema de drenagem na bacia é fortemente controlado pelas estruturas de ruptura nas rochas pré-cambrianas. São rios e riachos extensos, de cursos quase retilíneos, com ligeiras deflexões e com tributários laterais de pequena extensão. Esses canais se desenvolvem sobre zonas de fraqueza ao longo de contatos litológicos ou de densos fendilhamentos da crosta, associados a falhas e/ou fraturamentos regionais.

Foi possível reconhecer, na área de estudo, três regiões morfológicas transicionais: (i) a superior (Zona I), que inclui as nascentes dos cursos d'água, na qual o gradiente topográfico é suave e convergente em direção ao eixo da bacia, representado pelo vale do rio Curaçá; (ii) o trecho intermediário (Zona II), onde ocorre uma quebra de relevo e o gradiente topográfico se acentua na forma de rampas, que se estendem até os limites da planície de inundação inferior; e (iii) a inferior (Zona III), correspondente à região da extensa planície central, onde o gradiente se torna novamente suave, até 0 eixo da bacia. Essas três zonas estão delineadas por linhas brancas no mapa da Figura 5.

A zona quase-plana superior possui uma camada de intemperismo de pequena espessura $(<10 \mathrm{~m})$, conforme mostram os resultados das sondagens geoelétricas. A zona intermediária é caracterizada pela presença de um saprólito pouco espesso ou quase inexistente, de modo que as drenagens se instalam praticamente sobre a rocha cristalina fraturada. Representa, portanto, as áreas de recarga para o componente aquífero de fraturas regional. 


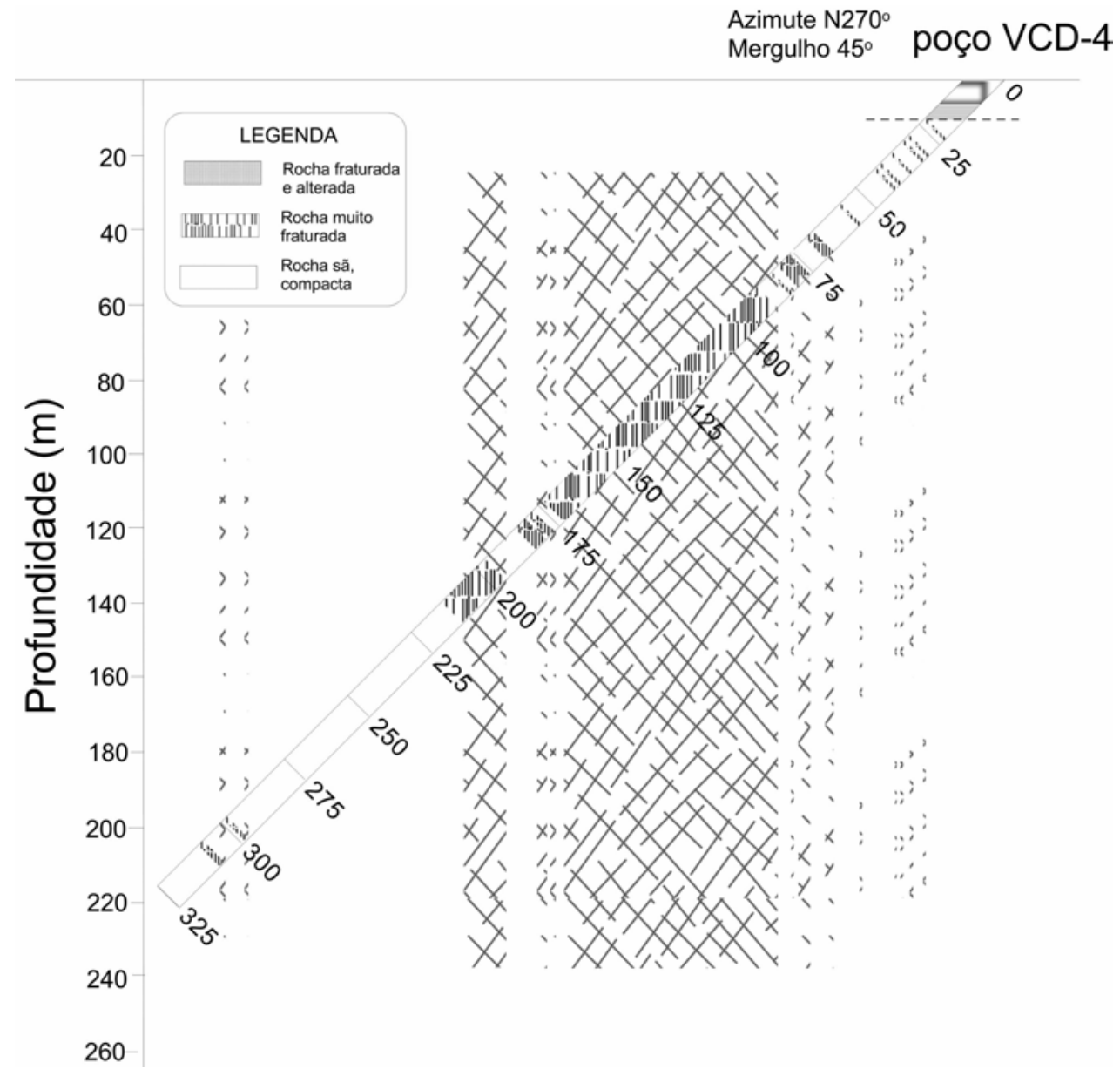

Figura 3 - Dados geológicos do poço de exploração mineral VCD-4 testemunhado pela Mineração Caraíba.

Na zona inferior das planícies, a camada de intemperismo é mais espessa e se associa aos depósitos aluviais dos vales para formar uma camada contínua de cerca de $20 \mathrm{~m}$ de espessura. Esta camada granular contém um componente aquífero livre, de pequena potência, mas de grande importância no controle da salinização da água subterrânea, conforme será explicado adiante.

\section{GEOFÍSICA AÉREA}

0 levantamento aerogeofísico executado para a CBPM no âmbito do projeto Riacho Seco/Andorinha inclui medidas de espectrometria de radiação gama natural, emitida por solos e rochas, e medidas do campo magnético total da Terra, ao longo das linhas de voo. Esse levantamento foi efetuado ao longo de linhas orientadas de Leste para Oeste e equiespaçadas entre si de $250 \mathrm{~m}$. A altura de voo foi fixada em $100 \mathrm{~m}$.

A Figura 2 mostra 0 mapa do campo magnético total observado sobre a mesma área da Figura 5. Magneticamente, se observa uma boa resolução das zonas das falhas Morro do Serrote, Morro da Caraíba, Riacho do Chico e Itiúba, assim como de vários conjuntos de falhas e fraturamentos regionais. Observase também uma nítida distinção entre as rochas de composições sieníticas e os diferentes gnaisses e rochas metabásicas a eles associadas.

A análise qualitativa das anomalias aeromagnéticas mostra boa concordância litológica e estrutural com o mapa geológico da Figura 1. As rochas plutônicas ácidas, de derivação magmática, se caracterizam como faixas anômalas mais positivas, intercaladas com unidades de paragnaisses e intrusivas sieníticas, que possuem susceptibilidades magnéticas mais baixas. Além disso, chama atenção 0 fato de que a ampla planície do rio Curaçá (Fig. 5) se associa a um conjunto de anomalias magnéticas positivas indicadas como lineamentos representativos de grandes falhamentos subverticais. Tal comportamento é consistente com a presença de faixas de rochas mais fraturadas e intemperizadas, 


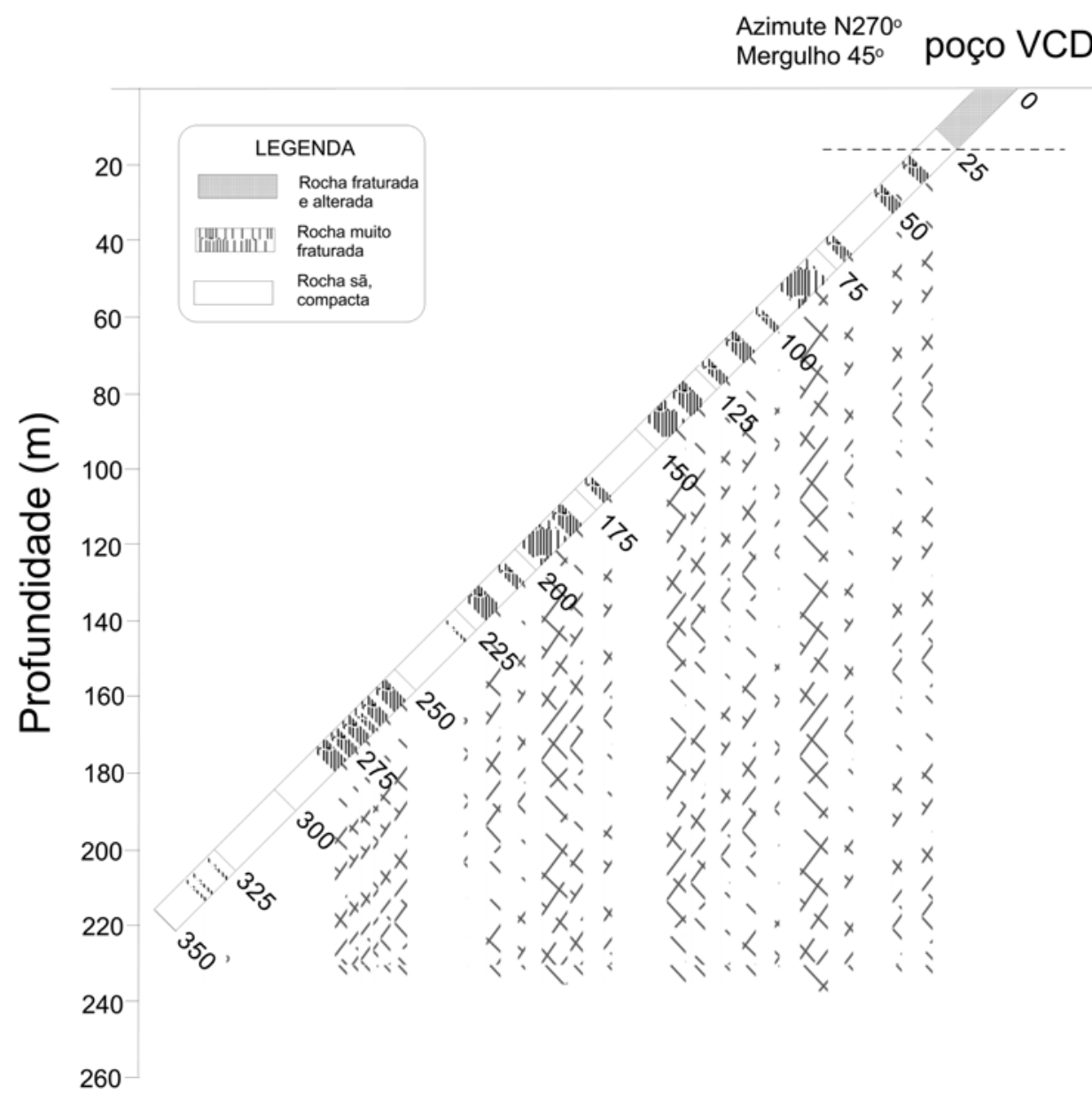

Figura 4 - Dados geológicos do poço de exploração mineral VCD-6 testemunhado pela Mineração Caraíba.

que se estendem até grandes profundidades, suficientes para sensibilizar o campo geomagnético.

\section{GEOFÍSICA TERRESTRE}

As estruturas dos aquíferos nas rochas cristalinas do vale do Curaçá, a qualidade das águas armazenadas e os riscos de sua contaminação pelas atividades da mineração foram avaliados usando métodos elétricos e eletromagnéticos. Neste trabalho, são considerados apenas os dados obtidos com o método elétrico convencional, envolvendo medidas simultâneas de resistividade e de polarização induzida no domínio do tempo (IP-resistividade).

Para mapear a geometria estrutural dos aquíferos e inferir sobre a qualidade das águas subterrâneas foi utilizada a técnica de imageamento geoelétrico bidimensional, a partir da execução de multi-sondagens de IP-resistividade em centros equiespaçados, expandidas ao longo de transversais que cruzam os lineamentos estruturais da área. Essa técnica, desenvolvida no CPGG/UFBA na década de 90 (Medeiros \& Lima, 1990), tem se mostrado muito eficiente para delimitar zonas aquíferas fraturadas, tanto lateralmente quanto em profundidade (Ferreira, 1999; Pinheiro Neto, 2000). Um total de 164 sondagens elétricas foi levantado com arranjo Schlumberger de eletrodos expandido até espaçamentos $A B / 2$ máximos variando entre 200 e $500 \mathrm{~m}$, ao longo de 10 perfis transversais, conforme indicado nos mapas das Figuras 4 e 5. Quatro sondagens elétricas isoladas foram distribuídas ao longo da área estudada para mapear as zonas de aluviões e o manto de alteração desenvolvido sobre as rochas gnáissicas.

Os dez perfis indicados no mapa da Figura 5 têm as seguintes características: (i) perfil 1, transversal ao riacho Pilar e ao rio Curaçá, localizada na área da Fazenda Caraíba (área da mineração), consistindo de 41 sondagens elétricas (SEVs), sendo 32 de $\mathrm{AB} / 2=200 \mathrm{~m}$ equiespaçadas de $200 \mathrm{~m}$ e 09 de $\mathrm{AB} / 2=$ $500 \mathrm{~m}$, equiespaçadas de $500 \mathrm{~m}$; (ii) perfis 2 e 3 , transversais ao rio Curaçá nas áreas das fazendas Bela Vista e Mari, consis- 


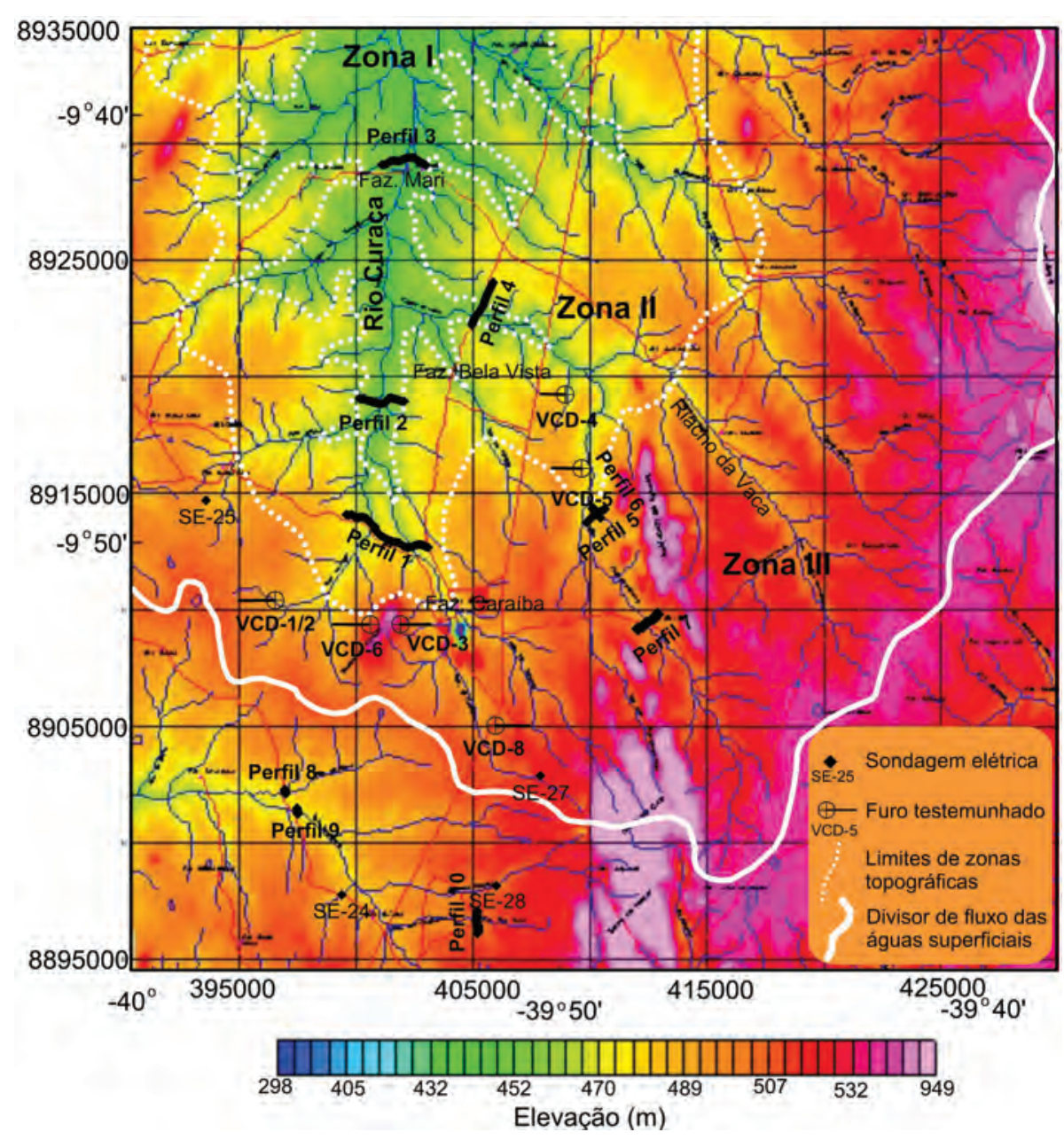

Figura 5 - Modelado do relevo e rede de drenagem da bacia do alto rio Curaçá no entorno da região de Pilar, Bahia.

tindo cada uma deles de $21 \mathrm{SEV}$, sendo 16 de $\mathrm{AB} / 2=200 \mathrm{~m}$, equiespaçadas de $200 \mathrm{~m}$ e 05 de $A B / 2=500 \mathrm{~m}$, equiespaçadas de $500 \mathrm{~m}$; (iii) perfil 4, transversal ao riacho da Vaca na área da Fazenda Poço da Vaca, consistindo também de $21 \mathrm{SEV}$ s, sendo 16 de $A B / 2=200 \mathrm{~m}$, equiespaçadas de $200 \mathrm{~m}$ e $05 \mathrm{de} \mathrm{AB} / 2=$ $500 \mathrm{~m}$, equiespaçadas de $500 \mathrm{~m}$; (iv) perfis 5 e 6 , transversal e paralelo ao riacho Poço de Januário, na área a jusante da bacia de rejeito da Mineração Caraíba, consistindo cada um de 10 SEVs com $\mathrm{AB} / 2$ máximo de $200 \mathrm{~m}$, equiespaçadas de $100 \mathrm{~m}$ entre si; (v) perfil 7 , transversal ao riacho Poço de Januário na área à montante da bacia de rejeitos, com $10 \mathrm{SEV}$ s de AB/2 máximo igual a $200 \mathrm{~m}$, equiespaçadas de $100 \mathrm{~m}$; (vi) perfis 8 e 9, transversais ao riacho Suçuarana ao longo da estrada para Santa Rosa, consistindo de 9 SEVs de $A B / 2=200 \mathrm{~m}$, equiespaçadas de $100 \mathrm{~m}$; e (vii) perfil, transversal ao riacho Suçuarana na localidade de Pedrosa, consistindo de $12 \mathrm{SEV}$ de $\mathrm{AB} / 2=200 \mathrm{~m}$, equiespaçadas de $100 \mathrm{~m}$.
Os dados de todas as sondagens elétricas realizadas na área foram invertidos uni e bidimensionalmente usando ajustes automáticos por mínimos quadráticos, com 0 auxílio dos programas de domínio público RES1D da Geotomo Software, e RESIST, de autoria de Vander Velpen \& Sporry (1993), bem como do programa comercial RES2DINV, também da Geotomo Software. RES1D foi utilizado na opção de inversão automática sem introdução de modelo inicial, visando obter um modelo geoelétrico de grande número de camadas bem ajustado aos dados experimentais (número de camadas do modelo igual ao número de pontos de medição na sondagem). RESIST foi usado para refinamentos com modelos de número menor de camadas, as quais preservam os principais intervalos geoelétricos da primeira inversão. Os dados de cargabilidade aparente foram invertidos usando os mesmos programas e uma segunda função resistividade aparente $\left(\rho_{a}^{*}\right)$, construída pelo produto da resistividade pela cargabilidade observada em cada ponto, $\rho_{a}^{*}=\rho_{a} m_{a}$, 
conforme proposto por Patella (1973). RES2DINV, foi empregado na inversão das seções simultâneas de resistividade e polarização induzida usando a técnica de otimização regularizada proposta por Loke \& Barker $(1995,1996)$; e Loke (1999), implementada usando a opção de suavizar os dados dos modelos geoelétricos.

Os dados das sondagens elétricas isoladas e de algumas das sondagens das seções transversais foram interpretados unidimensionalmente, no intuito de se efetuar uma caracterização litoestrutural preliminar das principais unidades geoelétricas ocorrentes na área. Nas Figuras 6 e 7 são mostradas algumas dessas sondagens, invertidas numericamente usando os programas indicados. Nelas se observa que, abaixo de uma camada fina de solo seco, se desenvolvem zonas de resistividade baixas (resistividades entre 5 e 70 ohm.m representando saprólitos ou depósitos aluviais recentes, saturados com águas salobras. Sob esses intervalos condutores ocorrem níveis mais resistivos (resistividade entre 30 e 300 ohm.m) e bem espessos, que representam rochas cristalinas fraturadas, sobrepondo-se à rocha compacta infinitamente resistiva. Os valores de cargabilidade são baixos na camada de solo e na zona vadosa do aquífero freático. Aumenta sensivelmente na zona saturada, de natureza aluvial ou saprolítica. Na transição saprólito - rocha fraturada, por causa da forte variação de porosidade, há uma pequena redução na cargabilidade que, em algumas sondagens e nas seções geoelétricas, tende a aumentar com a profundidade.

Na Figura 8 são mostradas imagens elétricas das funções resistividade aparente observada e calculada para 0 modelo final ajustado com RES2DINV ao ramo esquerdo do perfil 1, parte que cruza 0 vale do riacho Pilar. Esse modelo permite descrever a estrutura geológica da subsuperfície como composta de uma zona superior de estratificação subhorizontal, superposta a um substrato verticalmente estruturado, dentro dos limites de expansão de cada sondagem elétrica. Abaixo de uma camada superficial de solo seco se desenvolve um pacote lateralmente extenso, de baixa resistividade, aqui interpretado como constituído por sedimentos aluviais e por saprólitos, normalmente saturados com águas salobras. Nas zonas de vales, tais depósitos se acoplam eletricamente às zonas alteradas e fraturadas mais rasas, também saturadas de águas salobras. Na maioria dos riachos da área se observa a precipitação de cloreto de sódio, muito utilizado pelos gados bovinos e caprinos. Abaixo dos sedimentos aluviais ocorre a rocha cristalina sã seccionada, localmente, por largas zonas fraturadas, conforme indicado na seção geoelétrica inferior da Figura 8. Nas zonas mais densas de fraturas se observa valores de resistividade bem mais elevados que aqueles dos depósitos aluviais, que crescem gradativamente com a profundidade, indicando uma combinação da diminuição da porosidade do meio fraturado com a redução na salinidade da água com a profundidade. Uma ombreira central de elevada resistividade, logo abaixo da zona de saprólitos, separa as duas zonas fraturadas mais importantes da seção.

A Figura 9 mostra os resultados complementares do lado direito do perfil 1, agora cruzando o vale do rio Curaçá. Os resultados são similares aos da Figura 8, destacando-se: (i) a presença da camada superior condutiva e salinizada logo abaixo do solo; (ii) uma espessa e profunda zona de alta densidade de fraturas associada ao vale do Curaçá, com sua característica zona de transição elétrica em profundidade; e (iii) as ombreiras laterais à zona fraturada central, caracterizadas como rochas compactas, infinitamente resistivas.

A Figura 10 ilustra os resultados finais da inversão do perfil 2, que cruza o rio Curaçá na altura da Fazenda Bela Vista. Essa seção também fornece um modelo geológico similar aos das duas partes do perfil 1 , mostrando extensas coberturas condutivas, capeando zonas de densos fraturamentos (com resistividades ligeiramente mais elevadas). Tais zonas são ombreadas, lateralmente, por blocos rochosos compactos de elevadas resistividades. As seções das Figuras 8 a 10 representam as saídas gráficas do programa RES2DINV.

Na Figura 11A-B são mostradas as seções de resistividade e cargabilidade aparentes observadas ao longo do perfil 4, transversal ao curso do riacho da Vaca, na área da Fazenda Poço da Vaca. 0 riacho da Vaca tem seu curso controlado por zonas de fraturas de orientações NE, em contraposição a do rio Curaçá que é praticamente N-S. As seções C e D, na mesma figura, mostram os modelos finais invertidos para as distribuições de resistividade e cargabilidade elétricas da subsuperfície, com um erro médio quadrático de 4,5\%. Essas seções foram construídas usando 0 pacote SURFER 8.0 da Golden Software a partir dos arquivos de saída de RES2DINV. 0 modelo final de resistividade mantém as feições gerais descritas anteriormente, com zonas fraturadas mais estreitas paralelas ao riacho da Vaca. A seção de cargabilidade mostra um aumento geral de IP com a profundidade, em resposta a uma diminuição na salinidade da água. Todavia, há fortes variações laterais, abaixo de cerca de $30 \mathrm{~m}$ de profundidade, que resultam da presença de minerais sulfetados e grafita, disseminados nos gnaisses da área.

Os padrões destacados se repetem em todos os perfis geoelétricos realizados na área. As inferências sobre as variações de qualidade da água subterrânea são baseadas, basicamente, na associação dos resultados de IP e de resistividade derivados das 


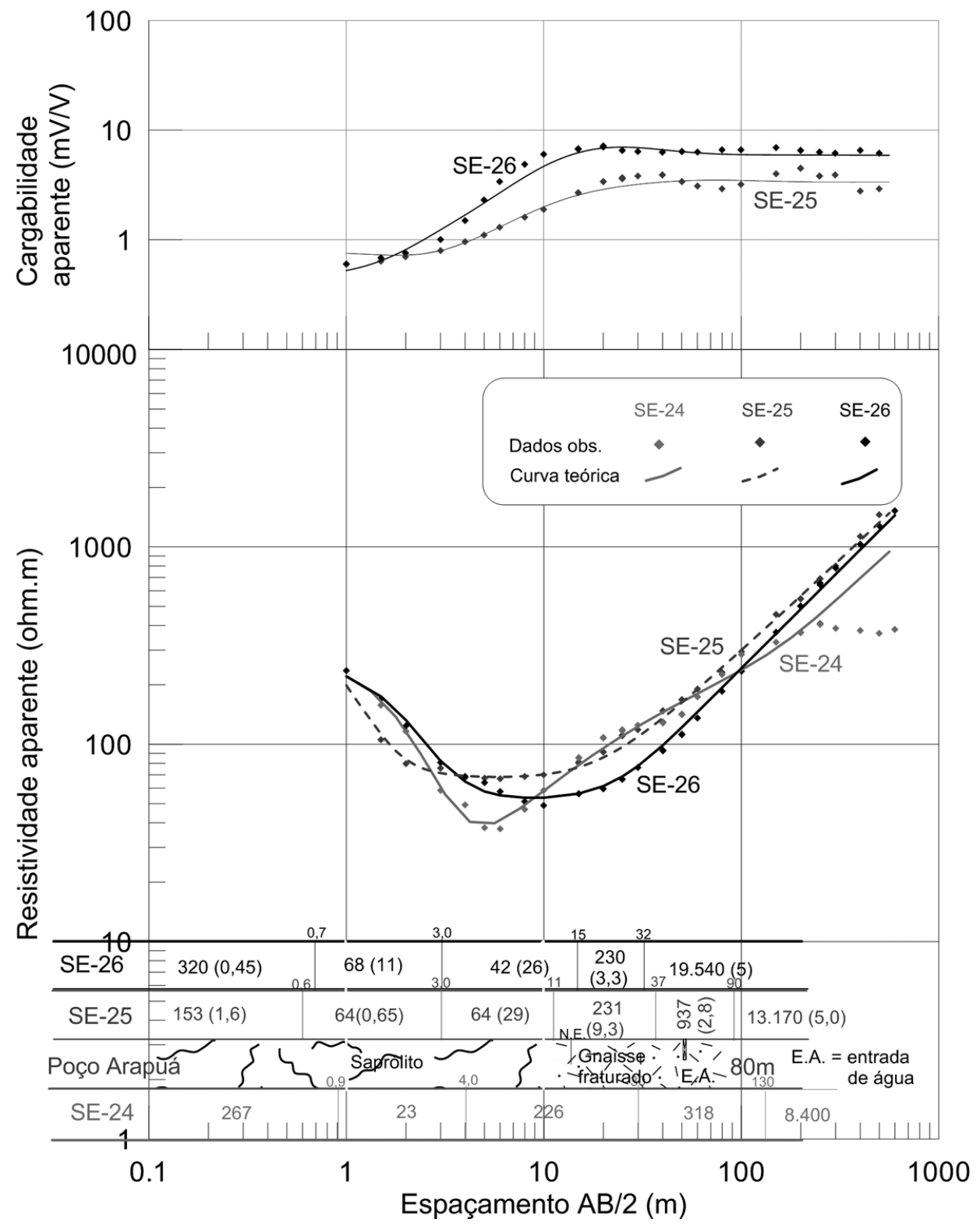

Figura 6 - Sondagens elétricas de IP-resistividade da área, sendo uma delas centrada em poço produtor de água.

imagens geoelétricas bidimensionais invertidas, uma vez que não existem poços nas proximidades das seções estudadas.

Os perfis geoelétricos invertidos revelam a presença de, pelo menos, dois sistemas aquíferos na área. 0 primeiro, relativamente extenso, mas de pequena espessura (pouco superior a $20 \mathrm{~m}$ ), possui resistividade e polarizabilidade elétricas bem baixas por causa da alta salinidade de sua água. É representado pelo material granular aluvial e por rochas cristalinas alteradas e fraturadas, numa condição de armazenamento de água sob pressão atmosférica. 0 segundo, de resistividade e polarizabilidade mais altas, parece conter água de melhor qualidade, sob condição que varia de livre a semiconfinada.

\section{HIDROGEOQUÍMICA}

Explicações sobre 0 alto grau de salinidade das águas armazenadas em rochas cristalinas do semi-árido nordestino têm sido apresentadas por vários hidrogeólogos, invocando diferentes mecanismos. Teixeira \& Oliveira (1962), Siqueira (1963) e Costa (1965), sugeriram que a salinização seria causada principalmente pela dissolução de minerais dessas rochas, especialmente bio- 


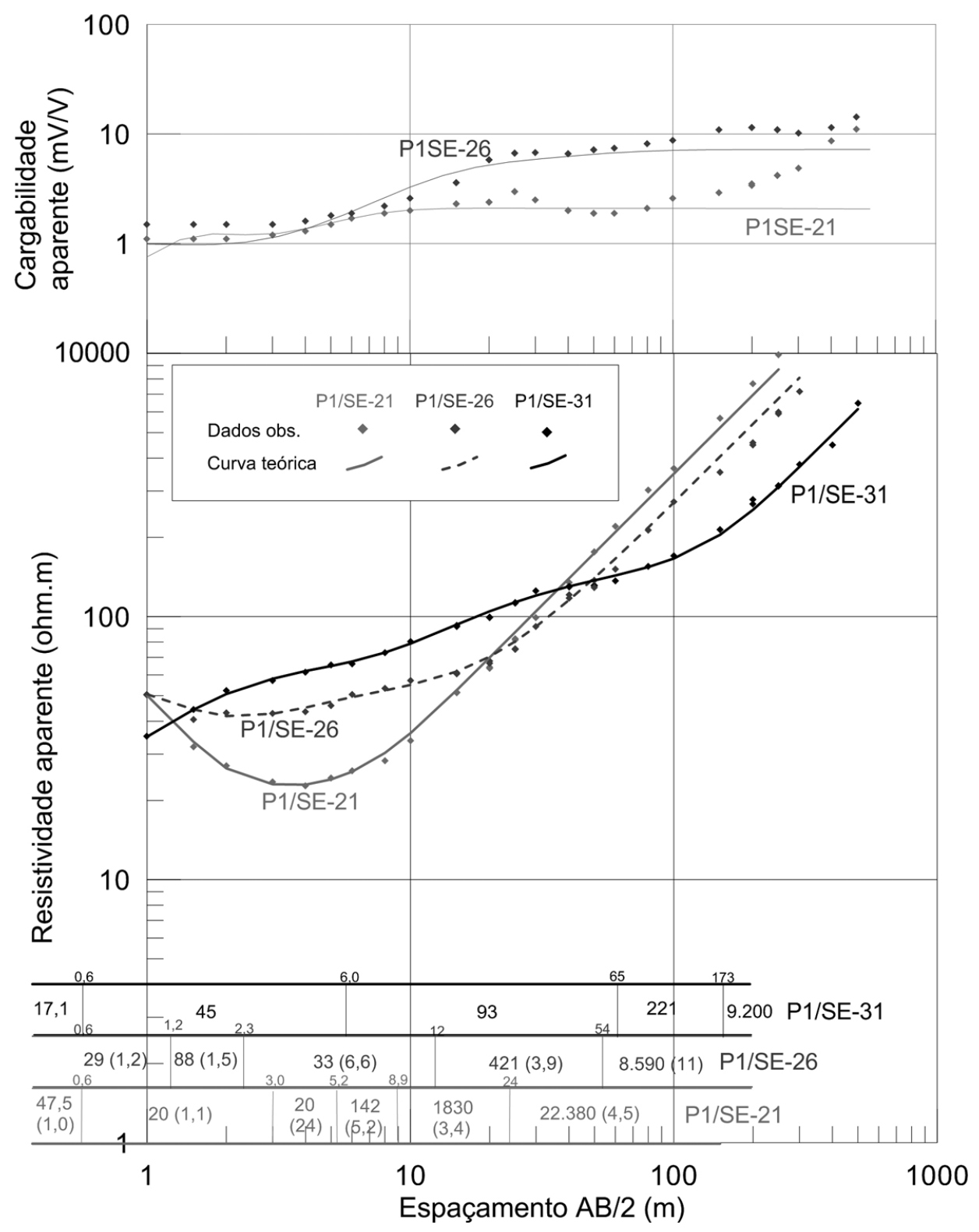

Figura 7 - Sondagens elétricas de IP-resistividade mostrando a presença de dois intervalos aquíferos em profundidade.

tita e feldspatos alcalinos. Leal (1966) propôs que a condição de aridez climática seria responsável pelo alto conteúdo mineral, tanto das águas superficiais quanto das subterrâneas. Para Schoff (1972), as águas salinas dos aquíferos cristalinos do semi-árido brasileiro teriam origem marinha, via sua introdução nas fraturas das rochas durante uma invasão do mar ocorrida no Cretáceo Superior. Esta água pretérita estaria sendo lentamente diluída pelas águas de chuvas que caem na região.

Os 231 poços de produção perfurados nos municípios de Jaquararí e Curaçá pela Companhia de Engenharia Rural da Bahia
(CERB) apresentam as seguintes características construtivas e de produção: (i) profundidades mínima e máxima de, respectivamente, $13,5 \mathrm{~m}$ e $150 \mathrm{~m}$, sendo que $10 \%$ do total têm profundidades inferiores a 50 m, 28\% estão entre 51 e 70 m, 41\% se estendem entre 71 e 90 m, e apenas 16\% têm profundidades superiores a $91 \mathrm{~m}$; (ii) as entradas de água (EA) mais frequentes (40\%) ocorrem a menos de $30 \mathrm{~m}$ de profundidade, mas a distribuição de EA parece mais regular, pois há registros de $34 \%$ de EA entre 31 e $50 \mathrm{~m}$ e $25 \%$ de EA abaixo de $50 \mathrm{~m}$; (iii) em termos de vazões tem-se os seguintes números: $35 \%$ desses 

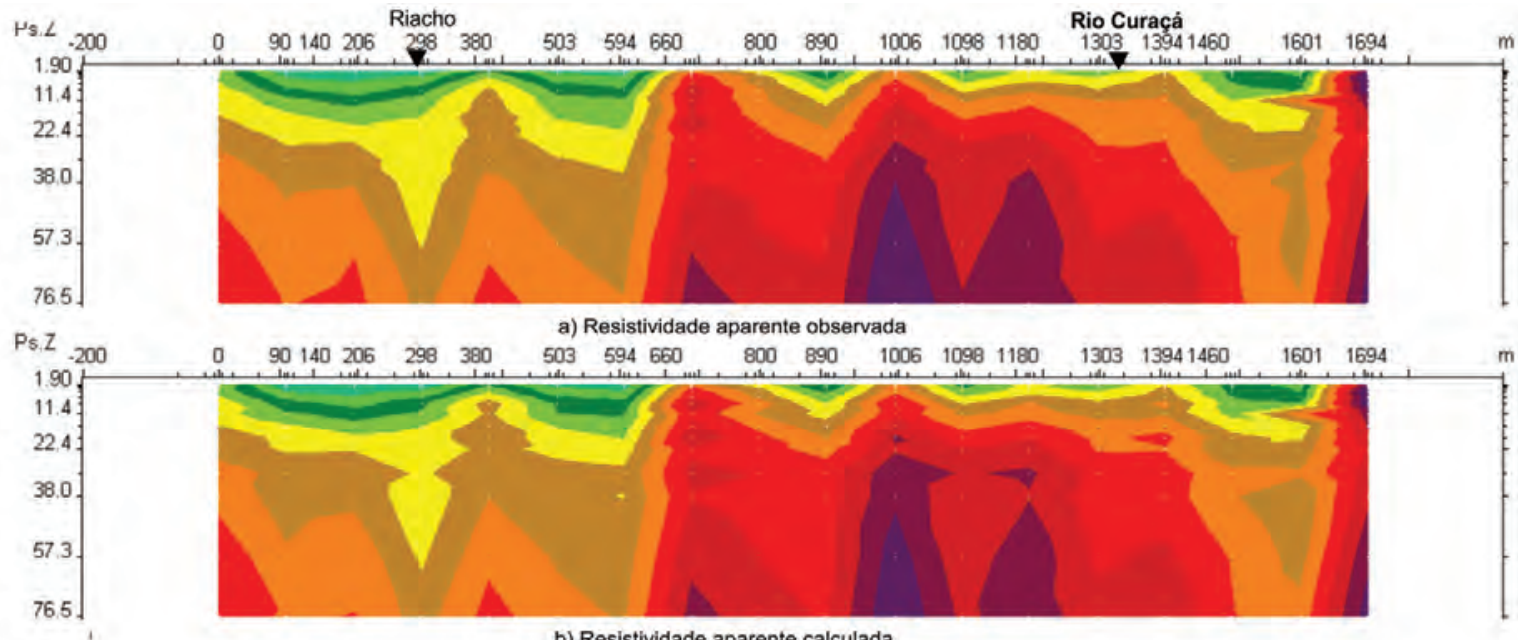

b) Resistividade aparente calculada
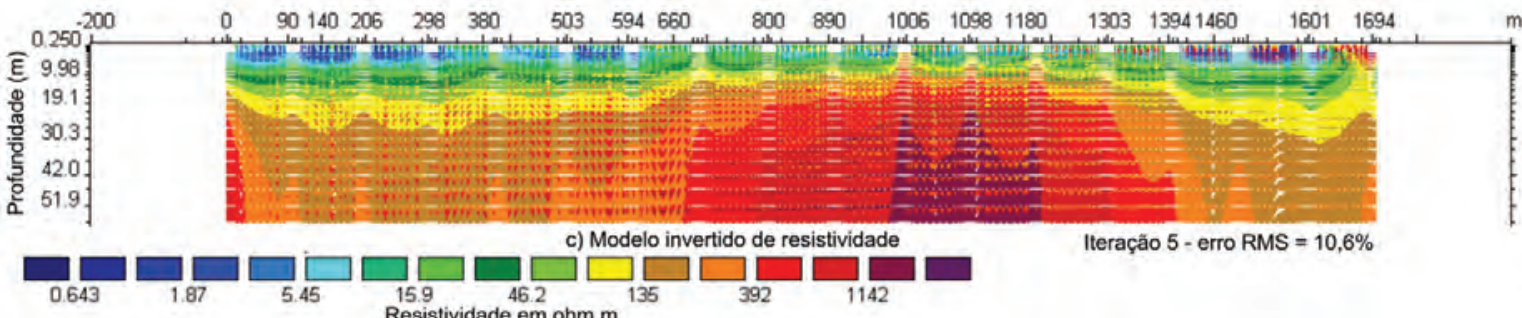

Figura 8 - Inversão geoelétrica do lado direito do perfil 1, efetuada com a opção robusta do programa RES2DINV.
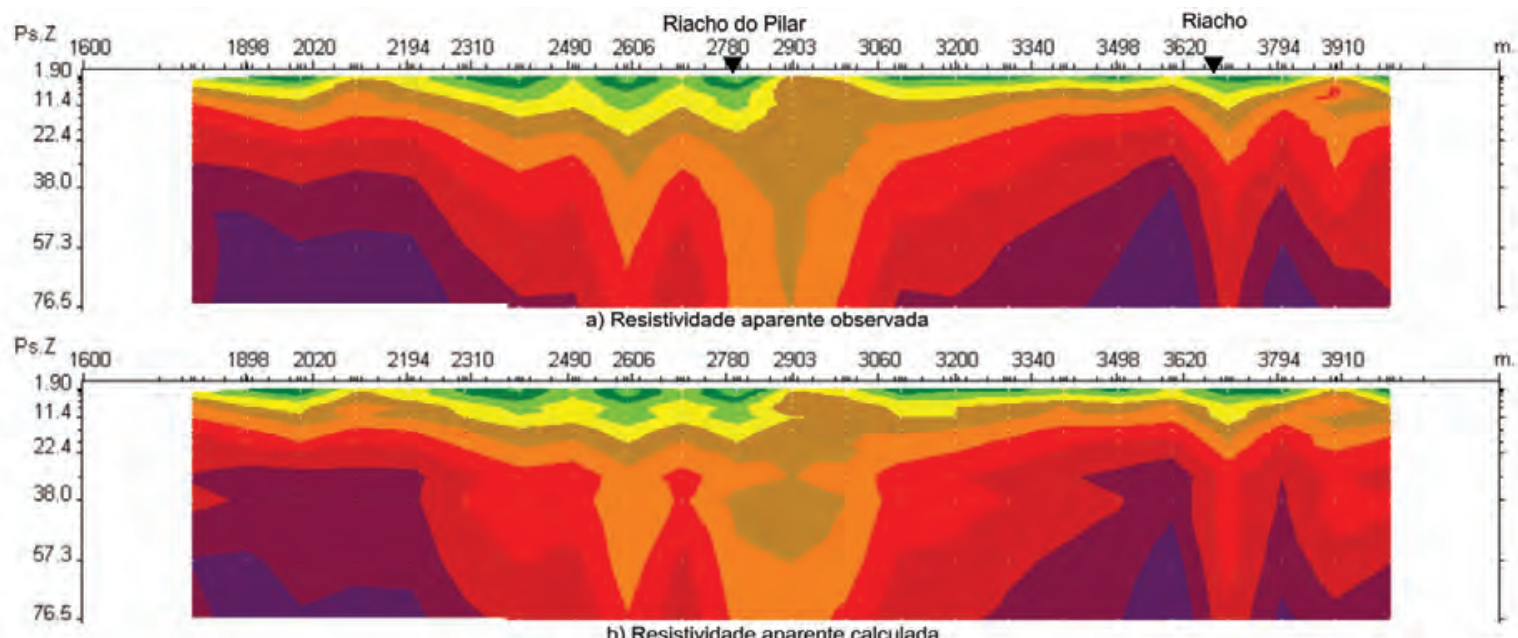

b) Resistividade aparente calculada
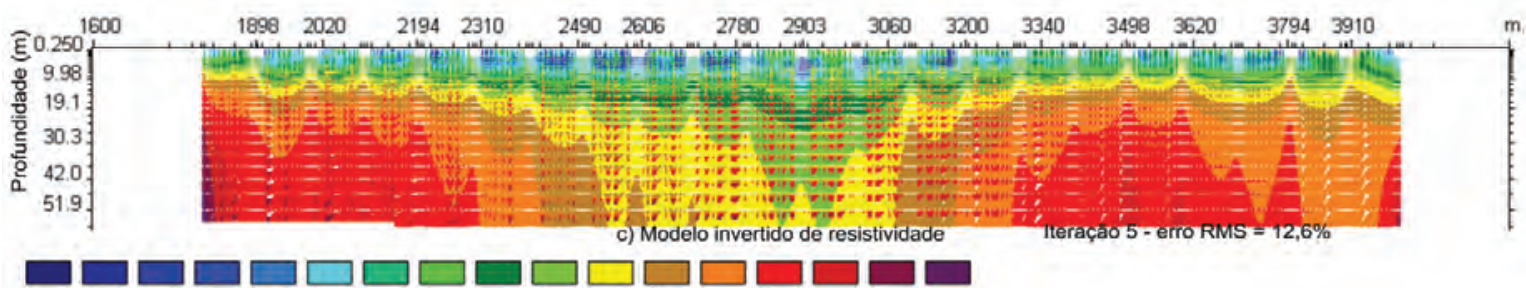

Figura 9 - Inversão geoelétrica do lado esquerdo do perfil 1, efetuada com a opção robusta do programa RES2DINV. 

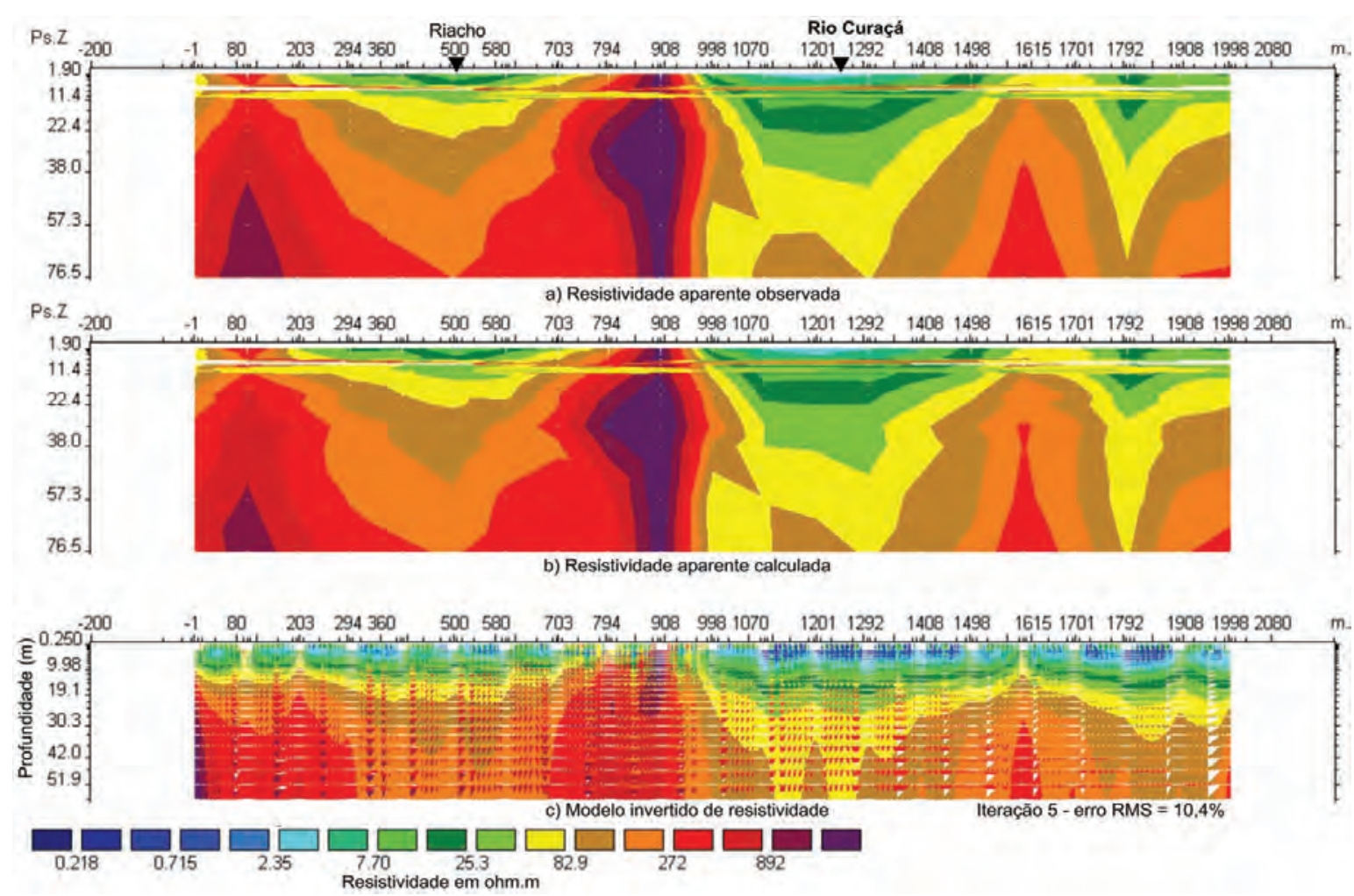

Figura 10 - Inversão geoelétrica de resistividade do perfil 2, transversal ao rio Curaçá na altura da Fazenda Bela Vista.

poços são secos ou têm vazões inferiores a $0,3 \mathrm{~m}^{3} / \mathrm{h} ; 70,2 \%$ têm vazões entre 0,3 e $5,0 \mathrm{~m}^{3} / \mathrm{h} ; 27 \%$ produzem entre 5,1 e $20 \mathrm{~m}^{3} / \mathrm{h}$, enquanto menos de $5 \%$ têm vazões acima de $20 \mathrm{~m}^{3} / \mathrm{h}$. Em geral, se observa que os poços de melhores vazões têm melhores distribuições verticais de EA e apresentam os menores totais de resíduos sólidos.

As concentrações de sais dissolvidos nas águas subterrâneas do vale do Curaçá mostram amplas variações e grandes diferenças composicionais. 0 resíduo sólido total (RT) nos 154 poços da CERB com análises físico-químicas disponíveis varia de $120 \mathrm{mg} / \mathrm{l}$ a mais de $26.900 \mathrm{mg} / \mathrm{l}$, com um valor médio de $5.097 \mathrm{mg} / \mathrm{l}$. Apenas 20,2\% desses poços apresentam RT abaixo de $1.000 \mathrm{mg} / \mathrm{l}$. Os dados observados nos municípios vizinhos de Juazeiro e Uauá mostram resultados estatísticos comparáveis.

Amostras de águas superficiais e subterrâneas foram coletadas como parte dos trabalhos do projeto HIDROCURAÇÁ. Os resultados de suas análises físico-químicas e isotópicas cobrem um amplo espectro de variação: (i) a condutividade elétrica varia de 300 a $15.000 \mu \mathrm{S} / \mathrm{cm}$, ou seja, de águas doces até águas muito salinas; (ii) as distribuições de sais solúveis maiores sugerem variações desde águas potáveis até quase águas do mar; (iii) valores isotópicos observados indicam uma boa correlação entre $\delta \mathrm{D}$ e $\delta^{18} 0$, com um ajuste de regressão linear por mínimos quadráticos dado por $\delta \mathrm{D}=6,6 \delta^{18} 0-4,2$. Os valores de $\delta \mathrm{D}$ e $\delta^{18} 0$ se concentram nas faixas de $-59 a+27 e-7,4 a+5,7$, indicando um grande enriquecimento isotópico causado pela forte evaporação característica do semi-árido (Lima, 2007).

Os resultados geológicos e geofísicos descritos no presente trabalho permitem propor o modelo hidrogeológico da Figura 12 para explicar o funcionamento hidráulico e os padrões de variação de salinidade da água observados nos poços até então perfurados no sistema aquífero cristalino da bacia do Curaçá. Trata-se de uma seção transversal ao curso do rio Curaçá, ao longo do perfil A-A' indicado na Figura 4, construída com base nos dados dimensionais obtidos no presente trabalho. 0 sistema contempla um componente freático de pequena espessura, mas de grande extensão lateral que, devido à semi-aridez climática, armazena águas de elevadas salinidades. Esse componente é composto de saprólitos, rochas alteradas fraturadas e depósitos aluviais. Nele, a dinâmica do fluxo hídrico é governada por extensas áreas de recargas e por uma forte evapo-transpiração concentrada ao longo dos vales de seus rios e riachos. As linhas cheias em cinza na Figura 12 representam, esquematicamente, as linhas de corrente, e as linhas interrompidas as linhas equipotenciais do 


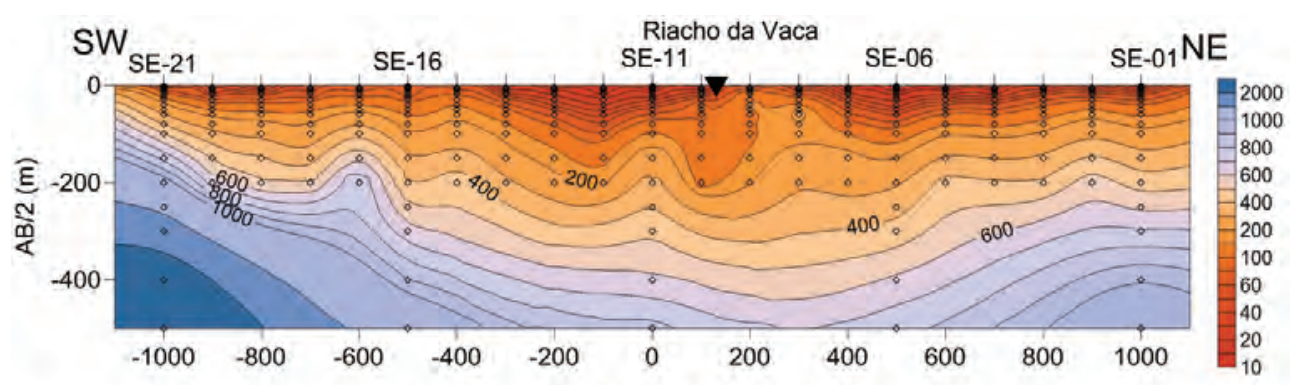

A) Seção de resistividade aparente observada (ohm.m)

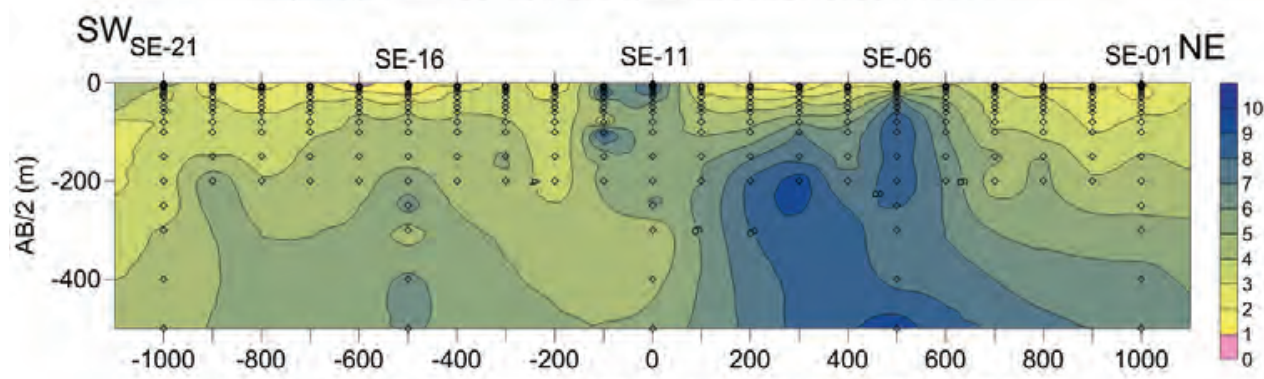

B) Seção de polarizabilidade aparente observada (mV/N)
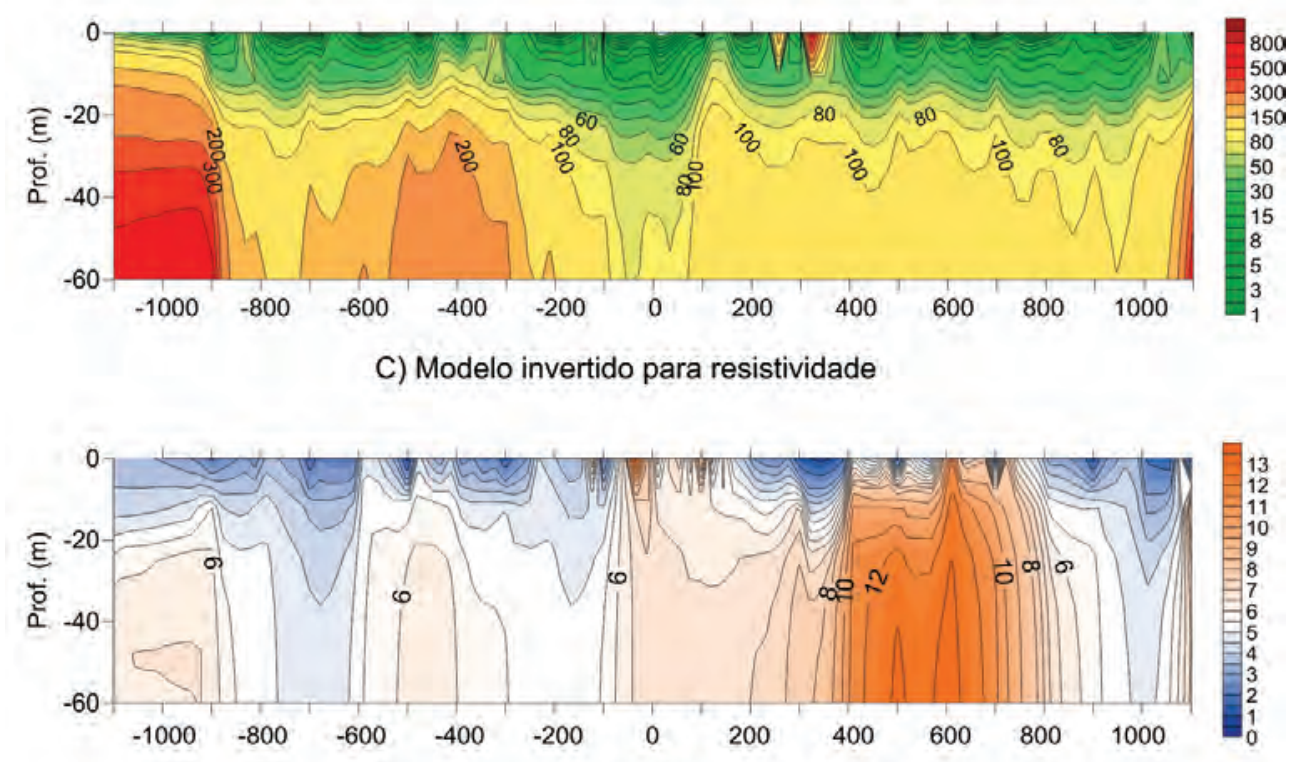

D) Modelo invertido para polarizabilidade

Figura 11 - Imagens geoelétricas de IP-resistividade ao longo do perfil 4, transversal ao riacho da Vaca.

fluxo. Nota-se que o fluxo é dominantemente subhorizontal nas zonas das vertentes e dominantemente subvertical ao longo dos vales. Pela aridez climática da área, esse padrão de fluxo prevalece na maior parte do ano, sendo alterado apenas no período das chuvas na bacia.

0 padrão de fluxo apontado prevalece entre os curtos períodos chuvosos (dois a quatro meses) da região. A forte evaporação na zona central determina a concentração de sais na superfície e ao longo da zona vadosa do componente aquífero freático, em função do tempo. A transpiração das plantas também extrai água do subsolo retendo sais na água residual. 0 sal retido na zona vadosa retorna ao aquífero no próximo período chuvoso. Por isso, a água desse componente aquífero freático tende a ter uma salinidade sempre crescente com o tempo. 


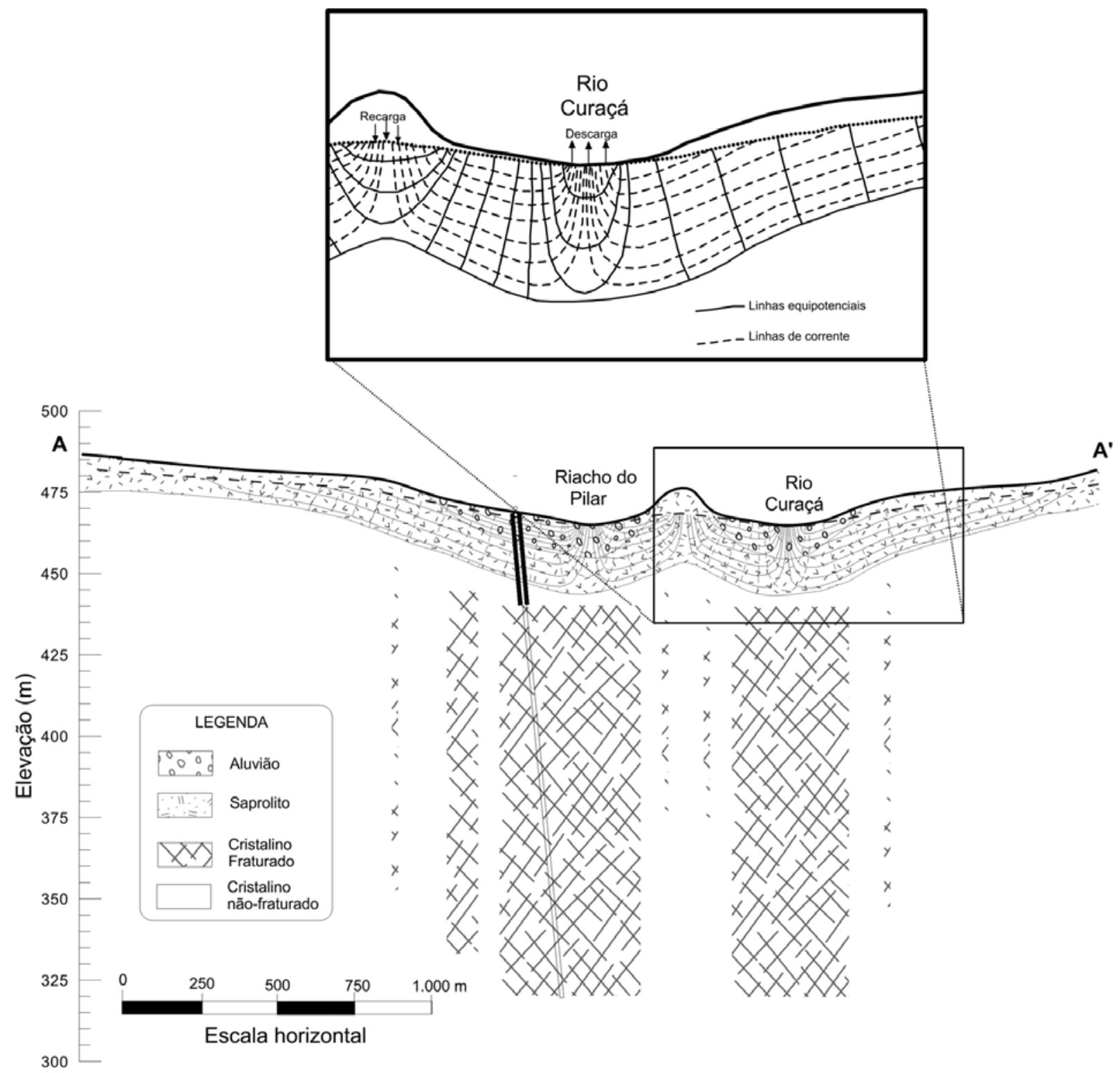

Figura 12 - Modelo hidrogeológico para os sistemas aquíferos da região cristalina da bacia do alto rio Curaçá. Zonas de fraturamentos e rede esquemática do fluxo da água no componente freático.

As rochas cristalinas gnáissicas, com altas densidades de fraturamentos subverticais entrecruzados, compõem 0 segundo componente aquífero. Essas fraturas podem permanecer abertas até grandes profundidades, pelo menos até $200 \mathrm{~m}$, conforme mostram os dados de poços de exploração da Mineração Caraíba. Zonas de fraturas de cisalhamento, com altos mergulhos, podem também se intercruzar com as fendas subverticias e favorecer 0 fluxo horizontal no componente fraturado, numa direção quase perpendicular à da seção da Figura 12. As zonas fraturadas são delimitadas por ombreiras de rochas cristalinas compactas, praticamente isentas de fraturamentos. 0 intercâmbio de água entre os dois componentes é suposto ser baixo, em função das condições hidrodinâmicas de seus fluxos naturais, controlados pela topografia do terreno.

Fica óbvio, nesse modelo, que as altas salinidades observadas nos poços do vale do Curaçá se devem, primariamente, à vazão de produção que é extraída, direta ou indiretamente, do armazenamento no componente aquífero freático. Uma forma de 
reduzir essa contribuição, em novos poços da área, é a de isolar nos poços com um colar de cimentação, a zona superior de até cerca de $30 \mathrm{~m}$ de profundidade, e explorar apenas as entradas de água abaixo de $30 \mathrm{~m}$. Para aumentar as chances de cortar o maior número de zonas fraturadas, é conveniente abrir os furos um com ligeiro desvio da vertical, algo em torno de 10 a $15^{\circ}$, conforme indicado na Figura 12.

\section{CONCLUSÕES}

As observações geológicas de afloramentos na bacia do Curaçá sugerem que, praticamente, todas as estruturas planas rúpteis têm alto potencial para armazenar e transportar águas. Isto é reforçado pela presença de falhas e fraturas de cisalhamento de cinemática normal, reativadas mais recentemente por eventos extensionais em níveis crustais mais rasos.

Os resultados apresentados permitem concluir pela viabilidade da exploração de recursos hídricos armazenados em rochas cristalinas do semi-árido brasileiro através do emprego de métodos geofísicos, sensoriamentos remotos e análises de dados estruturais, em apoio aos trabalhos hidrogeológicos convencionais. A metodologia de imageamentos geoelétricos bidimensionais por resistividade e polarização elétrica induzida, usando multi-sondagens equiespaçadas, mostrou-se adequada para mapear zonas de alteração e faixas fraturadas, em termos de suas extensões laterais e em profundidade.

A integração de métodos aerogeofísicos e terrestres possibilitou melhor entender a estrutura geológica da área e definir a presença de um sistema aquífero livre raso contendo água de elevada salinidade, que se superpõe a um sistema livre ou semiconfinado, provavelmente contendo águas de melhor qualidade.

Dados químicos e isotópicos das águas superficiais e subterrâneas revelam uma ampla variabilidade na concentração salina e apontam para uma forte atuação do processo de evapotranspiração, de acordo com 0 conjecturado por Leal (1966). A modelagem hidráulica aproximada de um sistema aquífero duplo, em regime de equilíbrio secular, sugere que a elevada salinidade da água subterrânea pode ser atribuída a um efeito climático, atuando em células de circulação hídrica rasas, controladas por um forte componente evapo-transpirativo.

A exploração de água em aquíferos cristalinos deve incluir a perfuração de poços desviados da vertical, alcançando profundidades da ordem de $200 \mathrm{~m}$ para aumentar as chances de se cortar o maior número de zonas fraturadas. Tais poços devem possuir uma zona superior cimentada a fim de se evitar a admissão de águas mais superficiais, sabidamente mais salinizadas.

\section{AGRADECIMENTOS}

0 autor agradece ao Conselho Nacional de Desenvolvimento Científico e Tecnológico (CNPq) pelo financiamento do projeto HIDROCURAÇÁ e pela Bolsa de Produtividade em Pesquisa. Agradece à Companhia Baiana de Pesquisa Mineral (CBPM) e à Mineração Caraíba pela liberação para a UFBA, respectivamente, dos dados do levantamento aerogeofísico de projeto Riacho Seco/Andorinha e dos dados das perfurações exploratórias do vale do Curaçá. Aos colegas L.C.V. Gomes, A.E.G. Azevedo, P.A. Pereira, L.N. Brito e F.D.S. Freitas pelas calorosas discussões e decisivas participações no projeto. Ao CPGG/UFBA pelo ambiente e apoio à execução do referido projeto.

\section{REFERÊNCIAS}

BARBOSA JSF \& DOMINGUEZ JM (Coords.). 1996. Geologia da Bahia: Texto Explicativo. 382 p. Salvador, SGM.

COSTA WD. 1965. Resumo hidrogeológico da região centro-sul da Paraíba. Água Subterrânea, 3: 18-24.

DELGADO IM \& SOUZA JD. 1975. Projeto Cobre-Curaçá: Geologia Econômica do Distrito Cuprífero do Rio Curaçá - Bahia - Brasil. Salvador: CPRM 30 v. Convênio CPRM/DNPM.

DOMENICO PA \& SCHWARTZ FW. 1997. Physical and Chemical Hydrogeology. New York. John Wiley \& Sons, Inc., 506 p.

FERREIRA NR. 1999. Inversão de dados de eletrorresistividade em meios bidimensionais. Tese de Doutorado em Geofísica. Univ. Fed. Bahia. 90 p.

FERREIRA FJF \& STEVANATO R. 2003. Abastecimento dos campi da UFPR por água subterrânea com base em imageamento elétrico 2-D e foto-interpretação. In: $8^{\circ}$ Cong. Internat. Soc. Bras. Geof., Expanded Abstract, Rio de Janeiro. CD-ROM.

JARDIM DE SÁ EP \& REINHARDT MC. 1984. Aspectos Metodológicos da Prospecção Mineral no Vale do Rio Curaçá - Bahia. In: Simpósio Brasileiro sobre Técnicas Exploratórias Aplicadas à Geologia, Anais. SBG, 250-278.

LEAL JM. 1966. Estudo geológico e hidrogeológico da bacia hidrográfica do rio Pajeú. SUDENE, Dept. Rec. Nat., 23 p.

LIMA OAL. 2007. Ciclo hidrológico e quantificação das reservas hídricas subterrâneas na bacia do Alto Curaçá, Bahia. Relat. Tec. Final Projeto HIDROCURAÇÁ. Apresentado ao CNPq/CT-HIDRO.

LOKE MH. 1999. Electrical imaging surveys for environmental and engineering studies: A practical guide to 2-D and 3-D surveys. Disponível em: <http://www.geoelectrical.com>. Acesso em: 16 maio 2003.

LOKE MH \& BARKER RD. 1995. Least-squares deconvolution of apparent resistivity pseudosections. Geophysics, 60: 1682-1690. 
LOKE MH \& BARKER RD. 1996. Practical techniques for 3D resistivity surveys and data inversion. Geophys. Prosp., 44: 499-523.

MEDEIROS WE \& LIMA OAL. 1990. A geoelectrical investigation for ground water in crystalline terrains of Central Bahia, Brazil. Ground Water, 28: 518-523.

MEDEIROS WE \& LIMA OAL. 1999. Origem do potencial elétrico espontâneo em rochas cristalinas fraturadas e sua utilização na locação de poços. Revista Brasileira de Geofísica, 17(2,3): 103-116.

OLIVEIRA EP. 1998. The Cu-rich Caraíba and Cr-rich Medrado Maficultramafic Complexes, Bahia, Brazil: U-Pb and Nd isotope constrains for Archaean lithospheric mantle remobilisation in the paleoproterozoic Salvador-Curaçá Orogen. In: Cong. Bras. Geol., 39., Belo Horizonte. p. 14.

PATELLA D. 1973. A new parameter for the interpretation of induced polarization field prospecting (Time domain). Gephys. Prosp., 21: 315-319.
PINHEIRO NETO V. 2000. Modelagem estrutural-geoelétrica de rochas cristalinas fraturadas. Tese de Doutorado em Geofísica, Univ. Fed. Bahia. $96 \mathrm{p.}$

SCHOFF SL. 1972. Origin of Mineralized Water in Precambrian Rocks of the Upper Paraíba Basin, Paraíba, Brazil. Contribution to Hydrology of Latin America and the Antilles. U.S. Geol. Survey Water-Supply Paper 1663-H.

SIQUEIRA L. 1963. Aspectos hidrogeológicos do Cariri Paraibano. SUDENE, Bol. Rec. Nat., 1(1): 11-44.

TEIXEIRA JA \& OLIVEIRA SPB. 1962. Perfuração de poços tubulares e levantamento geológico, Petrolina PE. SUDENE, 22 p.

VANDER VELPEN BPA \& SPORRY RJ. 1993. RESIST. A computer program to process resistivity sounding data on pc compatibles. Computer \& Geosciences, 19(5): 691-703.

\section{NOTA SOBRE O AUTOR}

Olivar Antonio Lima de Lima. Graduado em Geologia (1967) e Mestrado em Geologia (1970) pela Universidade Federal do Rio de Janeiro. Doutorado em Geofísica (1979) pela Universidade Federal da Bahia. Pós-doutorado em Petrofísica (1989-1990) no Departamento de Engenharia de Petróleo da Universidade do Texas, Austin - U.S.A. Professor Titular da UFBA e bolsista do CNPq nível IB. Áreas de pesquisa de interesse: aplicação de métodos elétricos e eletromagnéticos na exploração de petróleo, água subterrânea e problemas ambientais; propriedades físicas das rochas e perfilagem geofísica de poços. É sócio fundador da SBGf e membro ativo da SEG e da EAGE. 